\title{
Factors causing yield gap in rape seed production in the eastern of Mazandaran province, Iran
}

\author{
Esmail Nezamzade, ${ }^{1}$ Afshin Soltani, ${ }^{2}$ Salman Dastan, ${ }^{3}$ Hossein Ajamnoroozi ${ }^{1}$ \\ ${ }^{1}$ Department of Agronomy, Gorgan Branch, Islamic Azad University, Gorgan; ${ }^{2}$ Department of Agronomy, \\ Gorgan University of Agricultural Sciences and Natural Resources, Gorgan; ${ }^{3}$ Agricultural Biotechnology \\ Research Institute of Iran (ABRII), Karaj, Iran
}

\begin{abstract}
The reduction of yield gap and achievement yield potential of oil plants make a significant contribution to yield increases and oil production in developing countries. This research was carried out to investigate the factors causing yield gap associated with rape seed crop management in the Neka region, east of the Mazandaran province, Iran, through a field study during 2015-2016 and 20162017. Boundary line analysis (BLA) was only applied to crop management practices/inputs, e.g. sowing date and rate, fertilizer applications, etc. Boundary lines were fitted to the edge of the data cloud of crop yield versus management variables in data. The average yield in 100 farms was $2051 \mathrm{~kg} / \mathrm{ha}$. According to findings of BLA, an average yield, based on the optimum level of the 14 studied variables, was $3032 \mathrm{~kg} / \mathrm{ha}$ with a $981 \mathrm{~kg} / \mathrm{ha}$ yield gap per hectare. The average relative yield and relative yield gap for the 14 investigated variables were $68.35 \%$ and $31.65 \%$, respectively. Therefore, it can be concluded that the use of the boundary line analysis in yield gap studies can clearly show the yield responses to management factors and calculate the possible potentials. Thus, cultivation practice management of the studied variables in farmers' fields can lead to increased yield and reduced yield gap.
\end{abstract}

Correspondence: Afshin Soltani, Department of Agronomy, Gorgan University of Agricultural Sciences and Natural Resources, Gorgan, Iran.

E-mail: afshin.soltani@gmail.com

Key words: Attainable yield; boundary line function; managing factor; potential yield; relative yield.

Received for publication: 16 May 2018

Revision received: 8 November 2019.

Accepted for publication: 14 November 2019.

(C) Copyright: the Author(s), 2020

Licensee PAGEPress, Italy

Italian Journal of Agronomy 2020; 15:1280

doi:10.4081/ija.2020.1280

This article is distributed under the terms of the Creative Commons Attribution Noncommercial License (by-nc 4.0) which permits any noncommercial use, distribution, and reproduction in any medium, provided the original author(s) and source are credited.

\section{Introduction}

World food security in future would depend on the production of enough food for the global population, which is predicted to be over nine billion by 2050 (UNDP, 2011). Achieving food security in the current environment depends on realizing the potential yield from agricultural land (Hochman et al., 2016; Guilpar et al., 2017). Hence, improving crop yield is necessary in view of the increasing pressure and global demand for food. On the other hand, loss of high quality land, annual decline in crop yield, increased application of chemical fertilizers, and the adverse environmental impact of chemical inputs indicate that the development of new strategies is necessary to increase yield with the minimum environmental impact (Chapagain and Good, 2015). In addition, ensuring environmental sustainability leads to research in changing agricultural management practices (Gaydon et al., 2017). In this regard, it is necessary that the agricultural challenges are thoroughly analyzed and management factors modified, if necessary, to improve the sustainability of agricultural production, given the increased pressure exerted by agricultural production on natural resources to achieve food security (FAO, 2015). Therefore, it is necessary to identify specific solutions including estimating the yield gap, identifying the factors constraining production, and designing remedial strategies for a wide range of agricultural areas (Anderson et al., 2016). As a matter of fact, increase of cultivation area is not an appropriate way in the future; because this issue requires cultivation of wayside-lands with low-yield and little sustainability. Thus, assessment of yield gap for precise research can help the researchers a lot therefore to be informed of crop management for food production is one main responsibility of farm managers and farmers. Actually, inexact management can cause many performing circumstances that are harvested (actual yield) and there would be a considerable distance (yield gap) with the amount that can be harvested (potential yield). Nowadays, yield gap reduction in agricultural production is very important and responsive means to meet future food demands (van Ittersum et al., 2013; Espe et al., 2016; Beza et al., 2017; Shi-Yuan et al., 2017; Silva et al., 2017). Increasing potential yield can be achieved as a result of plant breeding and modern farming and a positive interaction between the two, while the elimination of the yield gap, achieved by the adoption of well-known innovations by farmers, is a faster way of ensuring potential yield increases (Fischer, 2015).

Yield gap analysis is providing a little estimation of increased production capacity which is one important component in designing food providing strategy in regional, national scale and world-wide surface (Grassini et al., 2013; van Wart et al., 2013; Fischer, 2015; Guilpart et al., 2017). Likewise, studies provide guidelines and specific recommendations on the causes of yield gap, which can 
include biophysical constraints such as biotic and abiotic stresses, poor land management, social and economic constraints such as restrictions on access to financial services and organizational or political restrictions, including market prices (van Oort et al., 2017). Yield gap detection requires accurate information of the biophysical environment, product management, as well as farm features and socioeconomic conditions of farmers; moreover, in the most period management factors are more effective on the yield gap than farm features and social and economic factors (Beza et al., 2017).

To estimate potential yields, many researchers have used several statistical methods to analyze data from $5 \%$ to $10 \%$ of the farmers who had the highest yields through field studies or face-to-face interviews (Egli and Hatfield, 2014). In these studies, if information regarding the sources of plant production and the different levels of inputs is gathered, it is possible to use statistical methods such as boundary line analysis (BLA) to determine the highest yield in response to a certain level of access to resources (van Ittersum et al., 2013). Tanaka et al. (2015) identified eight factors affecting the rice yield gap in Senegal, the main being the delay in planting, which resulted in a yield reduction of about one tone per hectare. The main causes of planting delay were lack of access to financial credit, machinery, irrigation water and other factors including fertilizer management and control of birds (Tanaka et al., 2015). In another research, a combination of useful variables (fertilizers, seeds, etc.) with agricultural data (available humidity, low-yield, etc.), geographical information (distance from the city, remote-area data, etc.) and other relevant information, showed a relatively new relationship and accounted for a variation of about $40 \%$ in wheat yield in Ethiopia (Mann and Warner, 2017). Of course, another research reported that the wheat yield gap in Argentina was $25 \%$ (De Paepe and Alvarez, 2016), in South East Australia 25\% (Rees et al., 2014), and in Oklahoma 26\% (Patrignani et al., 2014). Grassini et al. (2015) revealed a soybean yield gap in the United States between $10 \%$ and $30 \%$, and improved field yield in future related to early planting and the best fertilizer and fungicide use methods during the growing season. Abravan et al. (2016), in the Golestan province, Iran, through BLA of canola yield gap reported that the canola yield gap was $59 \%$ and its causes were low fertilizer use, planting density, and planting date. In another study in Alberta, the amount of rape seed yield gap was reported to be $30 \%$ (Chapagain and Good, 2015). As noted, many factors prevented farmers from achieving the crops' attainable yield. It seems that, by determining the effect of each affecting factor that had an effect on the amount of the yield gap and, consequently, the awareness of farmers, it is possible to minimize the gap between the actual yield and the attainable yield. Therefore, the objectives of this study were: i) determining and ranking the factors causing the rape seed yield gap; ii) to quantifying the rape seed yield gaps; and iii) estimating the yield gap related to crop management of rape seed by using BLA method under the climatic conditions of the eastern province of Mazandaran, in northern Iran.

\section{Materials and methods}

\section{Description of the site}

This experiment was carried out in the Neka area, east of the Mazandaran province, in 2015-2016 and 2016-2017. Neka city is located in the northern part of the Alborz Mountains range and south of the Caspian Sea in northern Iran (Gorjizad et al., 2019). The experimental region was geographically situated at $36^{\circ}-39^{\prime} \mathrm{N}$ latitude and $53^{\circ}-19^{\prime} \mathrm{E}$ longitude, west of the Mediterranean Sea. Local meteorological parameters data during the rape seed growing period were collected daily from the synoptic meteorological station nearest to the farms (Table 1). Solar radiation was estimated using sunshine hours and extraterrestrial radiation. For calculating solar radiation, the Srad_calc program was used. This program uses sunshine hour data to calculate solar radiation. For calculating day length, the PP_calc program was applied. Srad_calc and PP_calc programs can also be downloaded from https://sites.google. com/site/CropModeling.

\section{Data collection}

All the agricultural practices in this research, from the primary plough and seedbed preparation to harvest, was recorded by paddy field monitoring. For estimating yield gap, all agricultural practices were recorded, from seedbed preparation to the harvesting stage, in 100 fields via field monitoring. The method of each agricultural practice in the studied fields was determined for each of the phases of preparing soil, planting, cultivating, and harvesting.

Some important management measures were frequency and time of tillage operations (e.g. plough and disk cultivation), sowing date, seeding date, seeding rate, frequency and the amount of nitrogen fertilizer, the amount of phosphorus $\left(\mathrm{P}_{2} \mathrm{O}_{5}\right)$ and potassium $\left(\mathrm{K}_{2} \mathrm{O}\right)$ fertilizers, irrigation frequency and regimes, time and frequency of weed, disease and pest controls and harvesting date. Time of operations (e.g. planting date) was considered as day since 23 September, the beginning of autumn.

Table 1. Description of climatic parameters in the survey (2015-16 and 2016-17).

\begin{tabular}{|c|c|c|c|c|c|c|c|c|c|c|c|c|}
\hline Month & $\begin{array}{r}\text { Averag } \\
\text { temp. } \\
2015-16\end{array}$ & $\begin{array}{l}\text { min. } \\
\left({ }^{\circ} \mathrm{C}\right) \\
2016-17\end{array}$ & $\begin{array}{r}\text { Averag } \\
\text { temp } \\
2015-16\end{array}$ & $\begin{array}{l}\max . \\
\left({ }^{\circ} \mathrm{C}\right) \\
2016-17\end{array}$ & $\begin{array}{r}\text { Evapo } \\
(\mathrm{mm} / \mathrm{n} \\
2015-16\end{array}$ & $\begin{array}{l}\text { ation } \\
\text { onth) } \\
2016-17\end{array}$ & $\begin{array}{r}\mathrm{Ra} \\
(\mathrm{mm} / \mathrm{n} \\
2015-16\end{array}$ & $\begin{array}{l}\text { onth) } \\
2016-17\end{array}$ & $\begin{array}{l}\text { Mean r } \\
\text { humid } \\
2015-16\end{array}$ & $\begin{array}{l}\text { lative } \\
\text { y }(\%) \\
2016-17\end{array}$ & $\begin{array}{r}\text { Mean s } \\
\text { ho } \\
2015-16\end{array}$ & $\begin{array}{l}\text { Inshine } \\
\text { urs } \\
2016-17\end{array}$ \\
\hline Sep.-Oct. & 18.1 & 16.3 & 26.6 & 25.3 & 98.2 & 90.6 & 84.5 & 61.6 & 75 & 77 & 210.4 & 218.7 \\
\hline Oct.-Nov. & 10.9 & 11.3 & 18.8 & 18.7 & 44.4 & 36.9 & 106.5 & 71.8 & 80 & 82 & 156.9 & 111.7 \\
\hline Nov.-Dec. & 6.4 & 3.5 & 14.1 & 11.9 & 19.3 & 17.7 & 78 & 90.7 & 82 & 82 & 132.2 & 137.8 \\
\hline Dec.-Jan. & 6 & 4.4 & 14.5 & 12.2 & 18.8 & 19.9 & 64.7 & 10 & 84 & 83 & 143 & 141.7 \\
\hline Jan.-Feb. & 4.8 & 4 & 11.8 & 10 & 20.5 & 39.6 & 92 & 91 & 84 & 83 & 133.2 & 106.8 \\
\hline March.-Apr. & 8.5 & 6.3 & 14.2 & 14 & 30.8 & 44.4 & 59.2 & 19.2 & 55 & 84 & 97.7 & 187.2 \\
\hline Apr.-May & 10.9 & 10 & 18.3 & 17.1 & 72.1 & 66.1 & 63.4 & 49.7 & 81 & 84 & 175.4 & 152.5 \\
\hline May-Jun. & 16.6 & 15.9 & 23.3 & 22.7 & 113.2 & 116.1 & 16.6 & 12.8 & 82 & 80 & 197.3 & 197.5 \\
\hline Jun.-Jul. & 20.4 & 20.4 & 27 & 27.7 & 116.8 & 228.6 & 18.1 & 0 & 63 & 76 & 191.2 & 309.2 \\
\hline
\end{tabular}


The list of management variables recorded in the studied rapeseed fields are presented in Table 2. For several management practices/input, it was not possible to fit a boundary line because there was no relationship between the variables and the maximum yields. Therefore, crop yield was not limited by these variables, at the level where they are currently practiced

The studied fields were selected with the help of local experts to represent a wide range of situations. All the management practices/inputs (variables) were monitored and recorded without interfere with farmer operations. The manner of identifying farms covers all main production methods. Then, information pertaining to farm management was collected. For data collecting, all agricultural variables were first separated. In total, studied fields were different with respect to field area, agricultural practices, inputs used and seed yield were evaluated over the growing seasons from seedbed preparation to harvest. At the end of the growing season, the actual yield was registered.

\section{Yield gap assessment based on boundary line analysis}

The main steps adopted for seed yield gap assessment using boundary line analysis (BLA) in a specific region/area were (Hajarpoor et al., 2018; Gorjizad et al., 2019): i) selection of fields in the study area. If the study area is large (as it is in the present research) it can be divided to several rather homogenous sub-areas based on climate, soil and/or management system differences. To obtain satisfactory results, a wide range of farms/fields with very different practices/inputs for each of sub-areas, is required; ii) gathering information on management and inputs as they are applied by the farmers. Only the practices that are under control of the farmers are included. As many as possible agricultural practices need to be included; iii) application of BLA to the gathered data and interpret the results.

There is no approved protocol application of BLA (Gorjizad et al., 2019). In general, some points from the outer edge of the data cloud are chosen and a line is fitted to them. This boundary line specifies the highest attainable yield or the maximum yield under the influence of different levels of a certain variable.

Three general steps can be considered to obtain the boundary line as below (Shatar and McBratney, 2004; Makowski et al., 2007; Patrignani et al., 2014): i) examining the scatter plot of data: a scatter plot (XY chart) should be prepared with crop yield as dependent variable and one selected management variable (e.g. planting date or number of seed per $\mathrm{m}^{2}$ ) as independent variable. This step visualizes the data cloud and facilitates selecting a proper function to be fitted to the edge of data cloud; ii) selection of the data points from the edge of data cloud to be used in curve fitting: this can be done simply by eye or by one of the advanced statistical methods. There are some statistical methods to objectively select the outer points for curve fitting or directly fit a line to the outer edge of the data cloud (e.g. Milne et al., 2006). For more information in this terms, readers can refer to Schnug et al. (1996); Kitchen et al. (2003); Shatar and McBratney (2004); Makowski et al. (2007); Huang et al. (2008); Riffel (2012); Tasistro (2012); Banneheka et al. (2013) and Patrignani et al. (2014). For simplicity, in the present study is the selection of the data points from the outer edge of the data by eye and then fitting an appropriate function to the points; iii) the final step is to fit a function to the data points obtained from the second step. The findings of this step in a model that explained the response of maximum yield to different levels of the independent variable under examination. Parameter estimates of the model can be further used for interpretation.
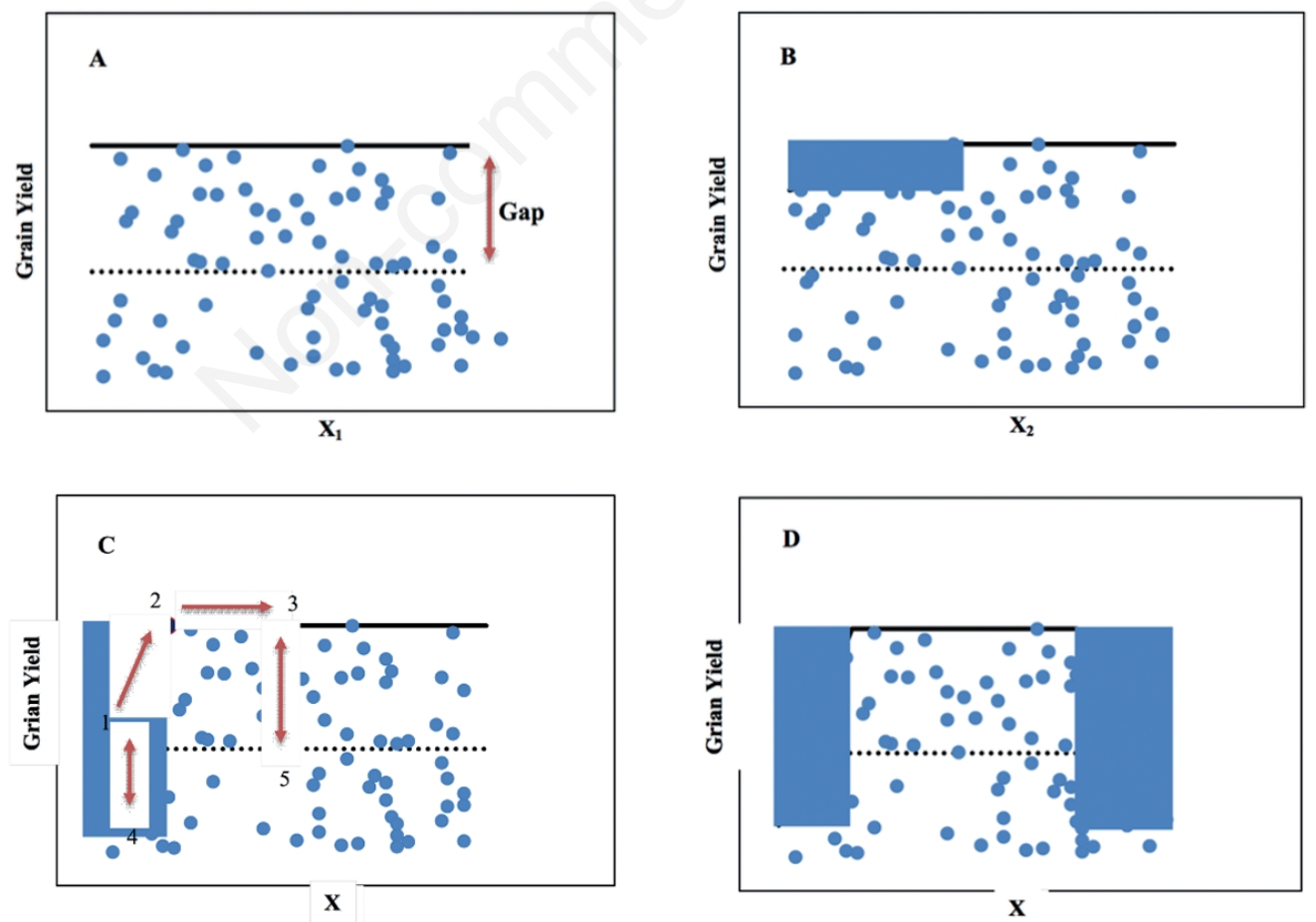

Figure 1. Scatter plots of the yield data vs managerial practices (X1-X4) in a hypothetical study (Hajjarpoor et al., 2018). The fitted bold line to the edge of the data cloud is the boundary line. The dotted horizontal line is the average of farmer's yield, the actual yield. The yield gap is the difference between the actual yield and potential yield. The potential yield is indicated by horizontal boundary line. The shaded area indicates lost yield area. 
Further explanation is provided using Figure 1 which represents scatter plots for four managerial variables $(x)$ in a hypothetical study (Hajjarpoor et al., 2018). For some variables, Figure 1A, BLA results in no model, i.e., there is no relationship between maximum yields and levels of the $x$-variable. A horizontal line can be fitted to the edge of the data cloud. This means maximum or potential yield is obtainable with every level of $x$-variable $\left(\mathrm{X}_{1}\right.$ in Figure $\left.1 \mathrm{~A}\right)$ within the observed range over the evaluated farms. If needed, an estimate of yield gap $\left(\mathrm{Y}_{\mathrm{g}}\right)$ can be obtained as difference between the horizontal line (potential yield; $\mathrm{Y}_{\mathrm{p}}$ ) and average farmers yield (actual yield; $\mathrm{Y}_{\mathrm{a}}$ - dotted horizontal line in Figure 1A):

$Y_{g}=Y_{p}-Y_{a}$

For managerial variables like $\mathrm{X}_{1}$, it is interpreted that they are not important under current conditions and cannot be considered as a cause for yield gap. The variables are not the causes of the yield gap and do not need to be considered further (Hajjarpoor et al., $2018)$. For other management variables of Figure $1\left(X_{2}, X_{3}\right.$ and $\left.X_{4}\right)$, the data cloud has a pattern so that maximum yields for different levels of $x$-variable cannot be describe by one straight horizontal line. Instead, two or more pieces of straight lines are required to describe the changes of the maximum yield (the edge of data cloud) versus different levels of $x$-variable (Figure 1B-D). Under such conditions, it can be concluded that these variables $\left(\mathrm{X}_{2}, \mathrm{X}_{3}\right.$ and $\mathrm{X}_{4}$; Figure 1B-D) are important variables and should be considered as causes of yield gap and need to be considered for improvement first under current production practices (Hajjarpoor et al., 2018). Therefore, a prime role of BLA in a complete yield gap assessment is to divide the management practices/inputs in two groups of nonimportant variables and the effective variables. However, not all the effective variables have the same importance in yield gap (please see below).

Segmented non-linear regression models with two or three segments so that the horizontal segment of the models presents maximum attainable yield or potential yield can be used to describe changes in maximum yield (the edge of the data cloud) versus different levels of variables $\mathrm{X}_{2}, \mathrm{X}_{3}$ and $\mathrm{X}_{4}$. Two-segmented model can be shown as:

$\mathrm{Y}_{\mathrm{x}}=\mathrm{a}+\mathrm{bX}$

if $\mathrm{X}<\mathrm{X}_{\mathrm{o}}$

$\mathrm{Y}_{\mathrm{x}}=\mathrm{a}+\mathrm{bX}$

if $X \geq X_{0}$

where $Y_{x}$ is the maximum yield for every level of $x$-variable, $X_{o}$ is the inflection point indicating minimum optimal level of $x$-variable over the examined fields, and $a$ and $b$ are regression coefficients. And, three-segmented model can be shown as:

$\mathrm{Y}_{\mathrm{x}}=\mathrm{a}+\mathrm{bX}$

$Y_{x}=a+b X_{01}$

if $\mathrm{X}<\mathrm{X}_{01}$

$Y_{x}=a+b X_{o 1}-c\left(X-X_{02}\right)$

if $X_{01} \leq X \leq X_{02}$

if $\mathrm{X}>\mathrm{X}_{\mathrm{o} 2}$

where $X_{01}$ and $X_{02}$ are two inflection points so that $X_{01}$ shows minimum optimal level of $x$-variable and $\mathrm{X}_{02}$ specifies maximum optimal level of $x$-variable and $a, b$ and $c$ are regression coefficients. $X$-variable levels lower or higher than the optimums result in yield penalty for the farmer. Potential yield $\left(\mathrm{Y}_{\mathrm{p}}\right)$ over the evaluated farms can be estimated as $Y_{p}=a+b X_{o}$ for the two-segmented model and as $Y_{p}=a+b X_{o 1}$ for the three-segmented model. Yield gap $\left(Y_{g}\right)$ can then be obtained as the difference between $Y_{p}$ and $Y_{a}$ (Hajjarpoor et al., 2018).

Variables $\mathrm{X}_{2}, \mathrm{X}_{3}$ and $\mathrm{X}_{4}$ do not have the same importance in yield gap. From the slope(s) of the relationship between $Y_{x}$ and $x$ - variable plus the percentage of the farmers that do not practice optimally with each of $\mathrm{X}_{2}-\mathrm{X}_{4}$, one can compare the importance of the variables. The farmers that do not practice optimally are those data points under sloping line(s) in Figure 1B-D. The number of the farmers with optimal management and the number of the farmers who are suffered from non-optimal management can be counted. Alternatively, the importance can be judged from the lost yield area as indicated in Figure 1B-D. For example, from comparison of Figure $1 \mathrm{~B}\left(\mathrm{X}_{2}\right)$ and Figure $1 \mathrm{C}\left(\mathrm{X}_{3}\right)$ it can be concluded that $\mathrm{X}_{3}$ is more important as non-optimal levels of $\mathrm{X}_{3}$ cause higher reduction in crop yield and the lost yield area (shaded area) is bigger for the variable (Hajjarpoor et al., 2018).

In Figure 1A-D, all the data points below the fitted line(s) are those farms where crop yield has been limited by other managerial practices/inputs. For example, in Figure $1 \mathrm{C}$, the yield difference between farms 1 and 2 is primarily due to non-optimal level $\mathrm{X}_{3}$ in farm 1 . However, the yield difference between farms 4 and 1 is due to non-optimal management of other variables in farm $4\left(\mathrm{X}_{2}, \mathrm{X}_{4}\right.$ or other variables not included in the analysis) as both the farms have received equal level of $X_{3}$. For example, if $X_{3}$ is nitrogen fertilizer, the lower yield in farm 4 may be due to non-optimal sowing date, seeding rate, etc. The same is true for yield difference between farms 5 and 3. BLA for $X_{3}$ cannot exactly say which management variables are responsible for the yield difference between farms 4 and 1. However, if BLA is applied to as many as possible managerial variables, those variables with a pattern (like $\mathrm{X}_{2}-\mathrm{X}_{4}$ in this example) are responsible for such differences (Hajjarpoor et al., 2018).

BLA, as described above, was applied to all management variables of the present study. The analysis was done separately for each of the production situations in the study, so that environmental variables such as rainfall have no significant effect on the obtained results. Thus, the resultant conclusions for each situation will be valid for same situation. SAS software was used to fit the selected functions (Eqs. 1 or 2; SAS, 2008). Finally, yield gap (Yg) is calculated as the difference between potential yield (Yp) and average farmers yield (actual yield) (Ya). The relative yield is estimated as [Ya / Yp $\times 100]$, which indicates how far or close farmers' yields are to Yp. Relative yield gap is obtained as [Yg / Yp $\times$ 100] (Soltani et al., 2016).

\section{Results and discussion}

For several management practices/input, it was not possible to fit a boundary line because there was no relationship between the variables and the maximum yields. These variables are listed in Table 2. Therefore, crop yield was not limited by these variables, at the level where they are currently practiced. Variables showing a relationship with yield were: production history, application of potassium, phosphorus, basal nitrogen, total nitrogen per hectare, nitrogen in the vegetative stages, nitrogen after flowering, and pesticides utilization (Figures 2-5). These variables were causes of yield gap and should be considered for the productivity improvement under the current conditions. Figures 2-5 present scatter plots of rape seed yield versus target management variables. Fitted lines in the figures represent the maximum yield $(\mathrm{Yx})$ for every given level of the variable under consideration and the horizontal line represent potential yield (Yp). All the data points below the lines represents situation in which the crop yield had been limited by other variables than the variable under examination (Kitchen et al., 2003). 
By fitting a line on the upper edge of the data (the highest selected yield in each domain), it was determined that the seed yield response (dependent variable) followed the independent variables, including production history, and potassium $\left(\mathrm{K}_{2} \mathrm{O}\right)$ application followed a positive two-piecewise function. But, application of phosphorus $\left(\mathrm{P}_{2} \mathrm{O}_{5}\right)$ and basal nitrogen $(\mathrm{N})$ followed a negative twopiecewise function. Total $\mathrm{N}$ application per hectare, $\mathrm{N}$ usage in the vegetative stages and herbicide utilization followed a threepiecewise function. Most variables, such as field area, $\mathrm{N}$ application after flowering, pesticide utilization, problems of crop lodging, pest, disease and weed, followed a linear gradient function and only the nitrogen variable had a positive gradient, while the other variables showed a negative gradient. The findings of these variables indicate that the function of the points below the boundary line is limited by other factors.

The average yield in 100 farms was $2051 \mathrm{~kg} / \mathrm{ha}$. The potential yield under the effect of farmers' production history was $2847 \mathrm{~kg} / \mathrm{ha}$, with a minimum optimal level of two years (Table 3 ). These results indicate that optimal yield could be attained with a two-year production history. $10 \%$ of the farms under the effect of farmers' production history were not optimal (Figure 2A). The relative yield of this variable was $72.4 \%$ and the yield gap was $796 \mathrm{~kg} / \mathrm{ha}(5.79 \%$ of the total), with a relative yield gap of $27.96 \%$ (Table 3 ). The BLA of the field area variable showed that $96 \%$ of the farms were out of the optimal level. The minimum optimal level for this variable was 0.38 hectares (Table 3 ). The yield based on the optimum level for this variable was $2786 \mathrm{~kg} / \mathrm{ha}$ and the yield gap was equal to 735 $\mathrm{kg} / \mathrm{ha}$ (35.5\% of the total). Relative yield and relative yield gap under the effect of field area variable were $73.62 \%$ and $26.38 \%$, respectively (Table 3; Figure 2B).

The results of the BLA of the application of $\mathrm{P}_{2} \mathrm{O}_{5}$ showed that the minimum optimal level was $66.2 \mathrm{~kg} / \mathrm{ha}$ and $12 \%$ of the farms were out of the optimal (Table 3) level. The yield based on the optimum level of this variable was $2811 \mathrm{~kg} / \mathrm{ha}$ with a yield gap of $760 \mathrm{~kg} / \mathrm{ha}(53.5 \%$ of the total) (Figure 2C). The relative yield and relative yield gap for $\mathrm{P}_{2} \mathrm{O}_{5}$ application was $72.96 \%$ and $27.04 \%$ (Table 3). For application of $\mathrm{K}_{2} \mathrm{O}$, the minimum optimal level 35.38 $\mathrm{kg} /$ ha followed a positive two-piecewise function (Figure 2D). The percentage of out-of-optimal farms under this variable was
$23 \%$. Seed yield, based on the optimal $\mathrm{K}_{2} \mathrm{O}$ level, was $2950 \mathrm{~kg} / \mathrm{ha}$, with a relative yield of $69.53 \%$. The yield gap and relative yield gap under this variable were $899 \mathrm{~kg} / \mathrm{ha}$ and $30.47 \%$ respectively, which was equivalent to $6.54 \%$ of the total yield gap of the 14 studied variables (Table 3).

Findings of the total $\mathrm{N}$ application indicate that $25 \%$ of the farms were out of the optimal level and the minimum optimal level was from 54 to $173 \mathrm{~kg} \mathrm{~N}$ per hectare. The seed yield, based on the optimal level for this variable, was $2740 \mathrm{~kg} / \mathrm{ha}$, which had a yield gap of 689 $\mathrm{kg} / \mathrm{ha}(5.02 \%)$ and a relative yield of $74.88 \%$. The relative yield gap for $\mathrm{N}$ application variables was $25.15 \%$ (Figure $3 \mathrm{~A}$ ).

The relative yield and relative yield gap of basal $\mathrm{N}$ application were $70.51 \%$ and $29.49 \%$ respectively (Table 3 ). The minimum optimal level for this variable was $59.54 \mathrm{~kg} / \mathrm{ha}$. This variable followed a negative-positive two-piecewise function, which showed that the basal $\mathrm{N}$ application up to $59.55 \mathrm{~kg} / \mathrm{ha}$ had no negative effect on the yield, while a rate above $59.54 \mathrm{~kg} / \mathrm{ha}$ caused yield reduction. The percentage of farms out of the optimal level for this variable was $4 \%$. The yield, based on the optimal level, was $2909 \mathrm{~kg} / \mathrm{ha}$ with a yield gap of $858 \mathrm{~kg} /$ ha equaling $6.25 \%$ (Figure 3B).

According to the results of Table 3, the minimum optimal level of $\mathrm{N}$ application in the vegetative stage was 58 to $72 \mathrm{~kg} / \mathrm{ha}$, and followed the three-piecewise function. The percentage of out-ofoptimal farms under this variable was $85 \%$. The seed yields, based on the optimum level and yield gap, were 2951 and $900 \mathrm{~kg} / \mathrm{ha}$, respectively and the yield gap was $6.55 \%$ of the total yield (Figure 3C). The relative yield and the relative yield gap for this variable were $69.5 \%$ and $30.5 \%$ respectively (Table 3 ).

The BLA for $\mathrm{N}$ application after flowering showed that the minimum optimal level was $65.7 \mathrm{~kg} / \mathrm{ha}$ and the percentage of outof-optimal farms was $74 \%$. Seed yield, based on the optimum level for this variable, was $2667 \mathrm{~kg} / \mathrm{ha}$ that $616 \mathrm{~kg} / \mathrm{ha}$ yield gap was $4.48 \%$ of the total yield (Figure 3D). The relative yield of this variable was $76.9 \%$ and the relative yield gap of this variable was $23.3 \%$ (Table 3 ). The data analysis of the pesticide variable demonstrated that the minimum optimal level was zero and the percentage of out-of-optimal farms was $27 \%$. The seed yield, based on the optimal level for this variable, was $3014 \mathrm{~kg} / \mathrm{ha}$ and the yield gap was $963 \mathrm{~kg} / \mathrm{ha}$ equals $7.01 \%$ (Figure 4A).

Table 2. The list of management variables recorded in the studied rapeseed fields. Name and type of variables

1 Variables related to farmers information: Name, gender, production history, and education level.

2 Variables related to Fields information: Village name, geographical coordinates, field area, previous crops, previous legumes name, previous years of legume cultivation, field position, direction of the field gradient, drainage and flooding problems, field leveling situation, leveling date and so on.

3 Variables related to seedbed preparation: Name and type of machinery and implements, date and no. of machinery utilization, tillage method, seedbed situation and humidity at the cultivation time, soil crusting problem and so on.

4 Variables related to crop fertilization: Fertilizer name, basal and top-dressing application, application date, crop growth stages at the application time, amount and method of fertilizer application, no. of top-dressing, amount and type of farmyard manure, and so on.

5 Variables related to cultivation: Seed rate, seed disinfection condition, seed disinfection material, cultivar name, cultivar type, source from which seed was acquired, satisfaction rate from seed, planting density, planting method, planting date and so on.

6 Variables related to crop protection: Pesticide name and type, the type of toxic group, the date and crop growth stages at the application time of pesticide, the amount and unit of pesticide application, the mode of pesticide application, the frequency of herbicide, insecticide, fungicide application and so on.

7 Variables related to weeding and other farming practices: Name of farming practice, date of practices, implements used for each operation and so on.

8 Variables related to harvest: planting density at harvest time, harvest date, type and name of harvesting machinery, seed yield amount, average seed yield of previous years, management of crop residue, problems of lodging, pests, diseases, weeds, harvest, type of combine machine, approximate percentage of seed falling, the most hazardous pests, diseases and weeds in the current year and previous years and so on.

9 Other investigated variables: The most important problem and proposed solution from the viewpoint of the farmer in the current year and the previous years, the effect of each agronomic and management factor on yield reduction from the viewpoint of the farmer and so on. 

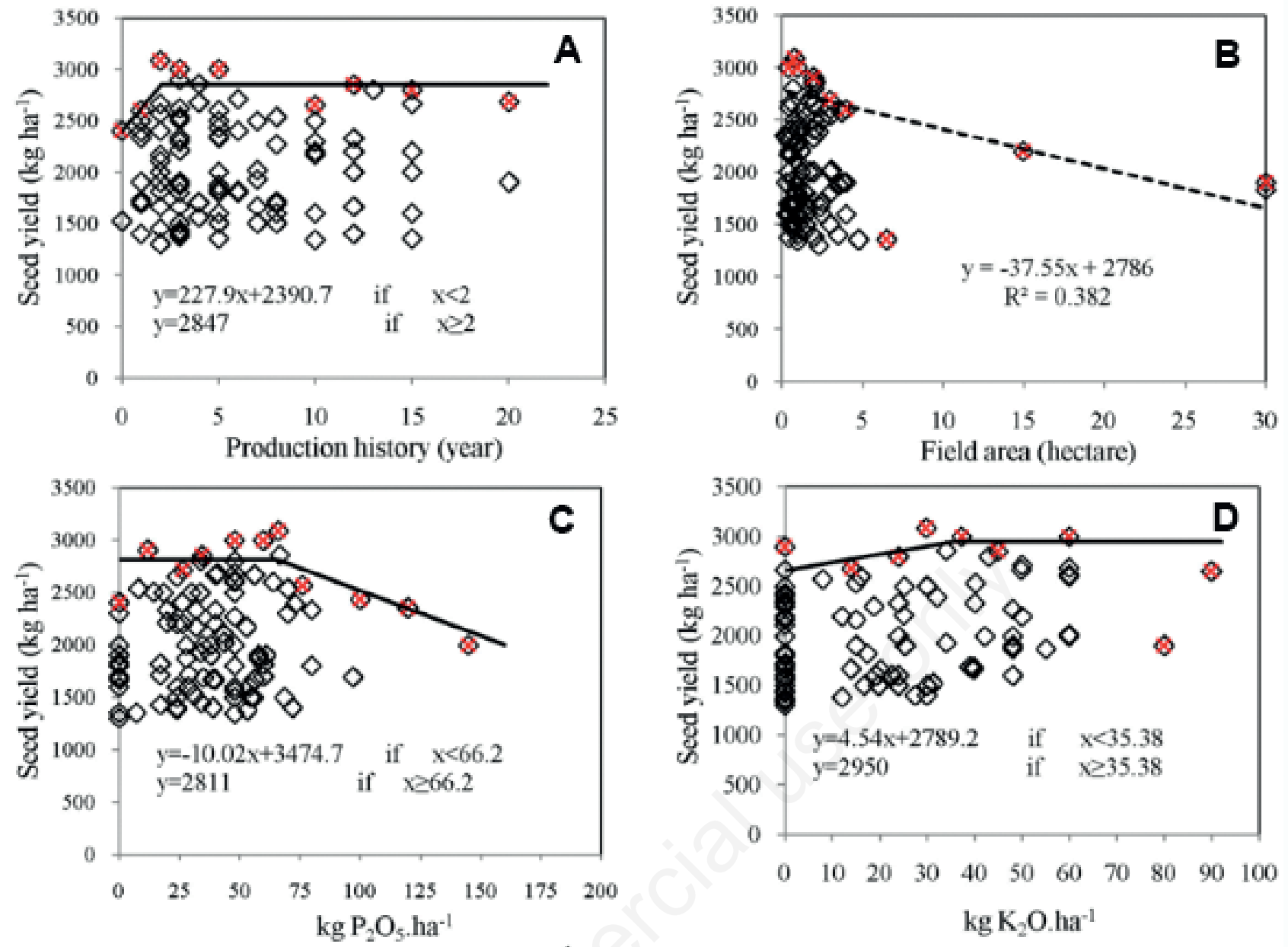

Figure 2. Scatter plots of seed yield data $v$ s production history (A), field area (B), $\mathrm{kg}_{2} \mathrm{O}_{5} \cdot \mathrm{ha}^{-1}$ and $\mathrm{kg} \mathrm{K}_{2} \mathrm{O} \cdot \mathrm{ha}^{-1}$ variables along with the fitted boundary line.

Table 3. Boundary line analysis along with estimation of potential yield and yield gap of canola.

\begin{tabular}{|c|c|c|c|c|c|c|c|c|}
\hline Variable & Unit & $\begin{array}{l}\text { Minimum } \\
\text { optimal } \\
\text { level }\end{array}$ & $\begin{array}{l}\text { Out of } \\
\text { optimal } \\
(\%)\end{array}$ & $\begin{array}{l}\text { Yield based on } \\
\text { optimal level } \\
\text { (kg/ha) }\end{array}$ & $\begin{array}{c}\text { Relative } \\
\text { yield } \\
(\%)\end{array}$ & $\begin{array}{l}\text { Yield } \\
\text { gap } \\
\text { (kg/ha) }\end{array}$ & $\begin{array}{l}\text { Relative yield } \\
\text { gap } \\
(\%)\end{array}$ & $\begin{array}{l}\text { Yield } \\
\text { gap } \\
(\%)\end{array}$ \\
\hline Production history & year & 2 & 10 & 2847 & 72.04 & 796 & 27.96 & 5.79 \\
\hline Field area & ha & 0.382 & 0.96 & 2786 & 73.62 & 735 & 26.38 & 5.35 \\
\hline Nitrogen & kg N.ha ${ }^{-1}$ & $54-173$ & 25 & 2740 & 74.85 & 689 & 25.15 & 5.02 \\
\hline Phosphorous & $\mathrm{kg} \mathrm{P}_{2} \mathrm{O}_{5} \cdot \mathrm{ha}^{-1}$ & 66.2 & 12 & 2811 & 72.96 & 760 & 27.04 & 5.53 \\
\hline Potassium & $\mathrm{kg} \mathrm{K}_{2} \mathrm{O} \cdot \mathrm{ha}^{-1}$ & 35.38 & 23 & 2950 & 69.53 & 899 & 30.47 & 6.54 \\
\hline Basal nitrogen & kg N.hat ${ }^{-1}$ & 59.54 & 4 & 2909 & 70.51 & 858 & 29.49 & 6.25 \\
\hline $\mathrm{N}$ in vegetative stage & kg N.ha ${ }^{-1}$ & $58-72$ & 85 & 2951 & 69.50 & 900 & 30.50 & 6.55 \\
\hline $\mathrm{N}$ after flowering & kg N.ha ${ }^{-1}$ & 65.7 & 74 & 2667 & 76.90 & 616 & 23.10 & 4.48 \\
\hline Pesticide (kg a.i.) & kg a.i. ha-1 & 0 & 27 & 3014 & 68.05 & 963 & 31.95 & 7.01 \\
\hline Herbicide (a.i.) & kg a.i. ha-1 & $1-2.96$ & 44 & 3030 & 67.69 & 979 & 32.31 & 7.13 \\
\hline Lodging problem & $*$ & 1 & 29 & 2946 & 69.62 & 895 & 30.38 & 6.52 \\
\hline Pests problem & $*$ & 1 & 8 & 3587 & 57.18 & 1536 & 42.82 & 11.18 \\
\hline Diseases problem & $*$ & 1 & 10 & 3885 & 52.79 & 1834 & 47.21 & 13.35 \\
\hline Weeds problem & $*$ & 1 & 64 & 3327 & 61.65 & 1276 & 38.35 & 9.29 \\
\hline Mean & - & - & - & 3032 & 68.35 & 981 & 31.65 & 100 \\
\hline
\end{tabular}

The problem of plant lodging problem, pests, diseases, weeds are: none (1), low (2), medium (3), high (4) and very high (5), respectively. ${ }^{*}$ The average yield in 100 fields was 2051 kg ha ${ }^{-1}$. 
The relative yield and relative yield gap for the pesticide variable were estimated to be $68.05 \%$ and $31.95 \%$ respectively (Table 3). The BLA of the applied herbicide variable showed that $44 \%$ of farms were out of optimal level (Figure $4 B$ ). The minimum optimal level for this variable was 1 to $2.96 \mathrm{~kg}$ active ingredient per hectare (Table 3 ). The seed yield, based on the optimal level for this variable, was $3030 \mathrm{~kg} / \mathrm{ha}$, with a yield gap of $979 \mathrm{~kg} / \mathrm{ha}(7.13 \%$ of the total). The relative yield and relative yield gap under the effect of the herbicide variable were $67.69 \%$ and $32.31 \%$, respectively (Table 3)

The results of the BLA of problem of crop lodging, pest, disease and weed was ranked as zero (0), low (1), medium (2), high (3) and very high (4). The results revealed that the minimum optimal level for these four variables was zero. The percentage of out-of-optimal farms with respect to lodging, pest disease, and weed problems were 29, 8, 10 and 64 percent respectively (Table 3; Figure 5A-D).

The yield, based on the optimal level for these four variables, was 2946, 3587, 3885 and $3327 \mathrm{~kg} / \mathrm{ha}$, respectively. The yield gap of these studied variables was $895,1536,1834$ and $1276 \mathrm{~kg} / \mathrm{ha}$, respectively, equaling $6.52 \%, 11.18 \%, 13.35 \%$, and $29.9 \%$. The relative yields of the four variables including problem of plant lodging, pest, disease, and weed were $69.62 \%, 57.18 \%, 52.79 \%$ and $61.65 \%$ respectively, and the relative yield gap of these four variables was $30.38 \%, 42.82 \%, 47.21 \%$ and $38.35 \%$, respectively (Table 3). An analysis of the BLA shows that an average yield, based on the optimal level of 14 studied variables, was $3032 \mathrm{~kg} / \mathrm{ha}$ with a yield gap of $981 \mathrm{~kg} / \mathrm{ha}$. The average relative yield and relative yield gap of the 14 studied variables were estimated to be 68.35 and 31.65 $\mathrm{kg} /$ ha respectively (Table 3 ).

Multivariate regression methods, despite certain advantages, are constrained by factors such as field conditions that are not limited by the BLA method, while; in BLA, only the effect of a factor or constraint is examined (Shatar and Mcbratney, 2004). With all these interpretations, it can be said that the calculated yield gap in this study is close to the definition given by the researchers regarding the exploitable yield gap functionality and shows the difference between the actual yield and achievable yield in relation to the environmental conditions of the region. One of the limitations of
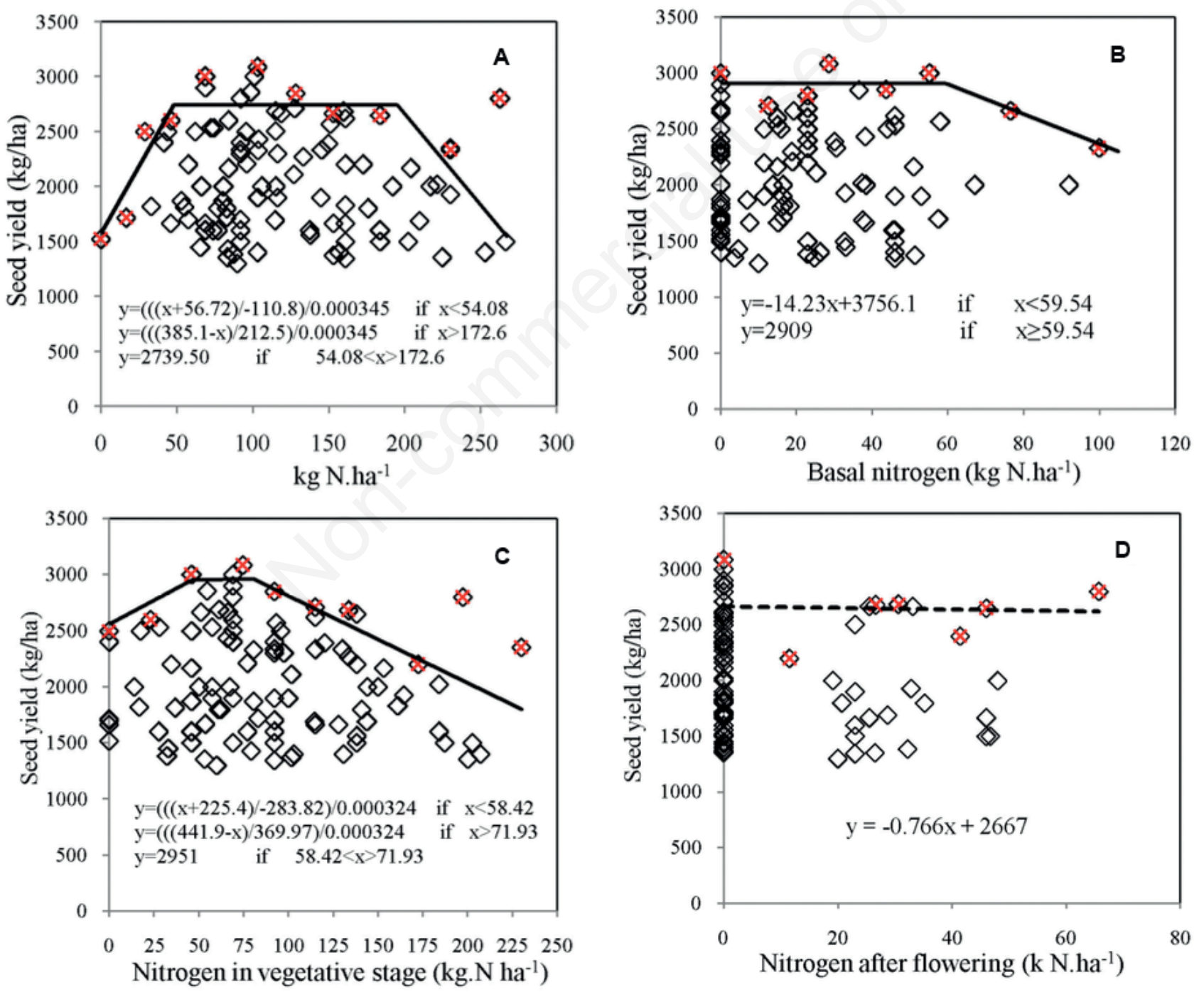

Figure 3. Scatter plots of seed yield data $v$ s total nitrogen applied (A), basal nitrogen (B), nitrogen in vegetative stage (C) and nitrogen after flowering usage (D) variables along with the fitted boundary line. 

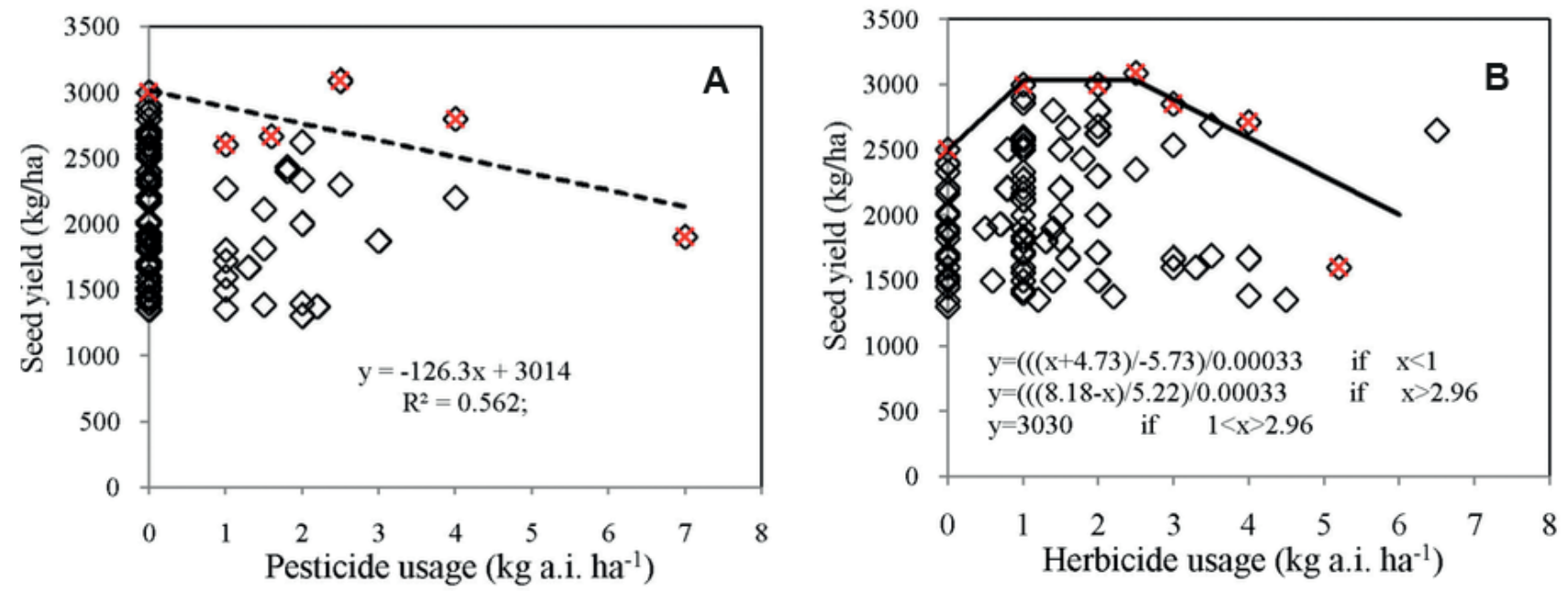

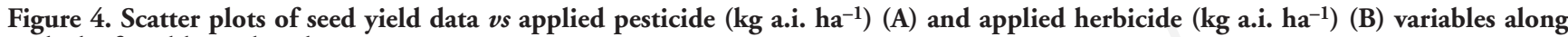
with the fitted boundary line.
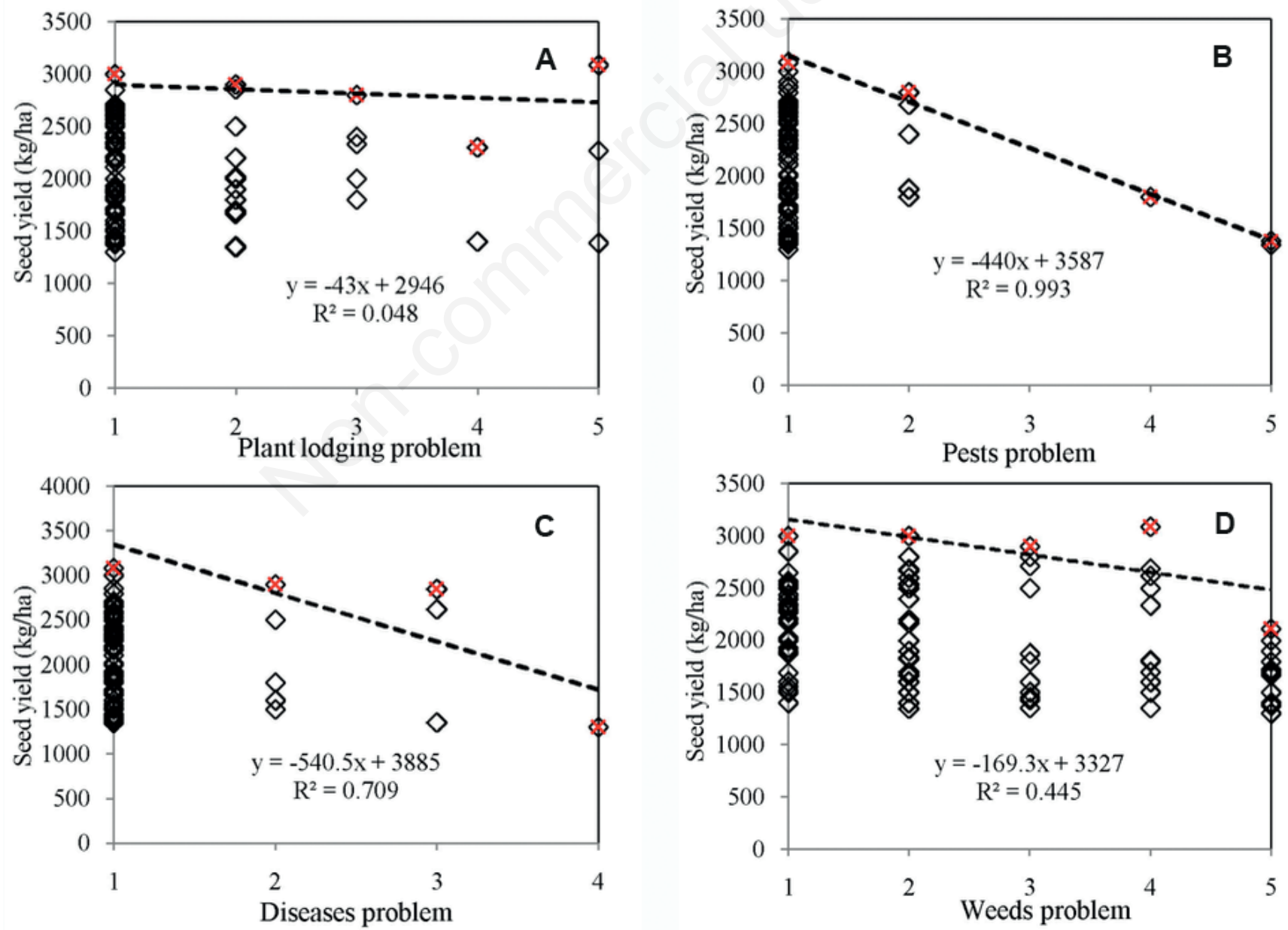

Figure 5. Scatter plots of seed yield data $v s$ plant lodging problem (A), pest problem (B), diseases problem (C) and weeds problem (D) variables along with the fitted boundary line. 
this research is the number of years of its implementation; the greater the number of years over which a study is conducted, the more accurate is the estimation of the impact of climate and climate fluctuations.

In order to reduce the yield gap, it is necessary to specify the yield constraints in a special area (van Ittersum et al., 2013). The BLA used in this study, estimates the yield gap and indicates the reasons for this yield gap and the yield constraining variable. In fact, one of the advantages of the BLA method, unlike the multivariate regression models, is that there is no need for the initial variable selection process. In addition, in the BLA method, the interpretation of results is simpler than in multivariate regression models (Shatar and Mcbratney, 2004). Given that the potential yield calculated in this analysis in the region is obtained from the actual data of each farm, the potential yield is dependent on the region, and it can be said that the potential yield is achievable.

In fact, multi-regional studies impose the effects of planting dates, harvesting dates, climate, and different soil conditions on the plant (van Ittersum et al., 2013), while there is no such limitation on the potential yield at a research station or in the simulation of yield potential with plant models. In general, the results of this study indicate that the use of the BLA method in yield gap studies can well illustrate the responses of managerial factors by identifying the contribution of each variable. Using these answers, researcher can determine the best management and planning to achieve the highest yield. Of course, the use of this method has a disadvantage as well, such as the interaction of variables affecting yield is considered nonsignificant and only analyzes the impact of one variable on yield, while, in reality; the yield is the result of the interaction of a set of factors (Kitchen et al., 2003). It is important to note that the use of other methods for estimating potential yields, such as the use of plant models along with BLA, can reveal important points of production constraints in a region.

The goal of many researchers is to increase the yield to a reasonable level to maintain food prices to the extent that it is both affordable for the consumer and is able to cover the costs for the farmer. It seems that a yield equal to $80 \%$ of potential yield is an economically desirable threshold in most planting systems (Lobell et al., 2009). Achieving yield above $80 \%$ of the potential yield is possible but may not be economically feasible for farmers in the area, given the cost of implements, machinery, fertilizers, pesticides and the overlapping planting seasons. In addition, empirical observations show that the most important yield gap problem in case of high-yielding crops in Iran is inefficient management practices in farms (Torabi et al., 2011; Soltani et al., 2016). Although, the purpose of this study was to estimate yield gap of rape seed, the reasons for this yield gap demand further study, but the most probable solution that can lead to increased yield and reduced yield deficit is improvements in crop management in farmers' farms. In addition, understanding the potential as well as the extent and the effect of each constraint factor separately plays an important role in formulating alternative management strategies to achieve the maximum yield.

\section{Conclusions}

Based on the findings of the 100 studied rape seed fields, an average yield, based on the optimum level of 14 variables, was 3032 $\mathrm{kg} / \mathrm{ha}$ with a yield gap of $981 \mathrm{~kg} / \mathrm{ha}$. Based on the findings, it can be stated that the accuracy of the model is suitable and can be used to estimate the yield gap and determine the contribution of each yield constraint variables, and it can be said that this potential yield is attainable. Using BLA in yield gap studies can clearly show yield responses to managerial factors and calculate possible potential. The interpretation of the BLA results is recommended that a dataset be subjected to several analytical methods with which BLA can be used as an applied analysis. It also seems that this analysis will reduce the need for conventional field experiments and provide the researcher (expert) with the right to design new field experiments. While such field studies are carried out extensively over several years, furthermore then more than the ability of such analyzes to find ways to increase production can be used.

\section{References}

Abravan P, Soltani A, Majidian M, Mohsenabadi Gh, 2016. Factors limiting canola yield and determining their optimum range by boundary line analysis. IIOAB J 7:161-7.

Anderson W, Johansen C, Kadambot H, Siddique M, 2016.Addressing the yield gap in rainfed crops: a review. Agron. Sustain. Dev. 36:18.

Banneheka B, Dhanushika M, Wijesuriya W, Herath K, 2013. A linear programming approach to fitting an upper quadratic boundary line to natural rubber data. J. Natl. Sci. Found. 41:13-20.

Beza E, Silva JV, Kooistra L, Reidsma P, 2017. Review of yield gap explaining factors and opportunities for alternative data collection approaches. Eur. J. Agron. 82:206-22.

Chapagain T, Good A, 2015. Yield and Production Gaps in Rainfed Wheat, Barley, and Canola in Alberta. Front. Plant Sci. 6:990.

De Paepe JL, Álvarez R, 2016. Wheat Yield Gap in the Pampas: Modeling the Impact of Environmental Factors. Agron. J. 108:1367-78.

Egli DB, Hatfield JL, 2014. Yield Gaps and Yield Relationships in Central U.S. Soybean Production Systems. Agron. J. 106:560-6.

Espe MB, Cassman KG, Yang H, Guilpart N, Grassini P, Wart JV, Anders M, Beighley D, Harrell D, Linscombe S, McKenzie K, Mutters R, Wilson LT, Linquist BA, 2016. Yield gap analysis of US rice production systems shows opportunities for improvement. Field Crops Res. 196:276-83.

FAO, 2015. Yield gap analysis of field crops - Methods and case studies. Available from: www.fao.org/

Fischer RA, 2015. Definitions and determination of crop yield, yield gaps, and of rates of change. Field Crops Res. 182:9-18.

Gaydon DS, Balwinder-Singh BE, Wang E, Poulton PL, Ahmad B, Ahmed F, Akhter S, Ali I, Amarasingha R, Chaki AK, Chen C, Choudhury BU, Darai R, Das A, Hochman Z, Horan H, Hosang EY, Vijaya Kumar P, Khan ASMMR, Laing AM, Liu L, Malaviachichi MAPWK, Mohapatra KP, Muttaleb MA, Power B, Radanielson AM, Rai GS, Rashid MH, Rathanayake WMUK, Sarker MMR, Sena DR, Shamim M, Subash N, Suriadi A, Suriyagoda LDB, Wang G, Wang J, Yadav RK, Roth $\mathrm{CH}, 2017$. Evaluation of the APSIM model in cropping systems of Asia. Field Crops Res. 204:52-75.

Gorjizad A, Dastan S, Soltani A, Ajam Norouzi H, 2019. Large scale assessment of the production process and rice yield gap analysis by comparative performance analysis and boundary-line analysis methods. Ital. J. Agron. 14:123-31.

Grassini P, Eskridge KM, Cassman KG, 2013. Distinguishing between yield advances and yield plateaus in historical crop production trends. Nat. Commun. 4: 2918. 
Grassini P, Torrion JA, Yang HS, Reea J, Andersen D, Cassman KG, Specht JE, 2015. Soybean yield gaps and water productivity in the western U.S. Corn Belt. Field Crops Res. 179:150-63.

Guilpart N, Grassini P, Sadras VO, Timsina J, Cassman KG, 2017. Estimating yield gaps at the cropping system level. Field Crops Res. 206:21-32.

Hajjarpour A, Soltani A, Zeinali E, Kashiri H, Ayneband A, Vadez V, 2018. Using boundary line analysis to assess the on-farm crop yield gap of wheat. Field Crops Res. 225: 64-73.

Hochman Z, Gobbett D, Horan H, Garcia JN, 2016. Data rich yield gap analysis of wheat in Australia. Field Crops Res. 197: 97-106.

Huang X, Wang L, Yang L, Kravchenko AN, 2008. Management Effects on relationships of crop yields with topography represented by wetness index and precipitation. Agron. J. 100:1463.

Kitchen NR, Drummond ST, Lund ED, Sudduth KA, Buchleiter GW, 2003. Soil electrical conductivity and topography related to yield for three contrasting soil-crop systems. Agron. J. 95:483-95.

Lobell DB, Cassman KG, Field CB, 2009. Crop yield gaps: their importance, magnitudes, and causes. Annu. Rev. Environ. Resour. 34:179-204.

Makowski D, Dore T, Monod H, 2007. A new method to analyze relationships between yield components with boundary lines. Agron. Sustain. Dev. 27:119-28.

Mann ML, Warner J, 2017. Ethiopian wheat yield and yield gap estimation: A spatially explicit small area integrated data approach. Field Crops Res. 201:60-74.

Milne AE, Ferguson RB, Lark RM, 2006. Estimating a boundary line model for a biological response by maximum likelihood. Ann. appl. Biol. 149:223-34.

Patrignani A, Lollato RP, Ochsner TE, Godsey CB, Edwards JT, 2014. Yield gap and production gap of rain-fed winter wheat in the southern Great Plains. Agron. J. 106:1329-39.

Rees H, McClelland T, Hochman Z, Carberry P, Hunt J, Huth N, Holzworth D, 2014. Leading farmers in South East Australia have closed the exploitable wheat yield gap: Prospects for further improvement. Field Crops Res. 164:1-11.

Riffel JD, 2012. Yield response and economic impact of variablerate nitrogen applications in grain sorghum. M.Sc. Thesis of Kansas State University. 115 p.
Schnug E, Heym J, Achwan F, 1996. Establishing critical values for soil and plant analysis by means of the Boundary Line Development System (Bolides). Commun. Soil Sci. Plant Anal. 27:2739-48.

Shatar TM, Mcbratney AB, 2004. Boundary-line analysis of fieldscale yield response to soil properties. J. Agric. Sci. 142:553-60.

Shi-Yuan Z, Xiao-hu Z, Xiao-lei Q, Liang T, Yan Z, Wei-xing C, Lei-lei L, 2017.Quantifying the spatial variation the potential productivity and yield gap of winter wheat in China. J. Integr. Agric. 16:845-57.

Silva JV, Reidsma P, Laborte AG, van Ittersum MK, 2017.Explaining rice yields and yield gaps in Central Luzon, Philippines: An application of stochastic frontier analysis and crop modeling. Eur. J. Agron. 82:223-41.

Soltani A, Hajjarpoor A, Vadez V, 2016. Analysis of chickpea yield gap and water-limited potential yield in Iran. Field Crops Res. 185:21-30.

Tanaka A, Diagne M, Saito K, 2015. Causes of yield stagnation in irrigated lowland rice systems in the Senegal River Valley: Application of dichotomous decision tree analysis. Field Crops Res. 176:99-107.

Tasistro A, 2012. Use of boundary lines in field diagnosis and research for Mexican farmers. Better Crops Plant Food. 96:11-3.

Torabi B, Soltani A, Galeshi S, Zeinali E, 2011. Assessment of yield gap due to nitrogen management in wheat. Aust. J. Crop Sci. 5:879-84.

UNDP, 2011. United Nations: World population to reach 10 billion by 2100 if fertility in all countries coverage's to replacement level. Press release 3 May 2011. Available from: www.unpopulation.org Accessed: 1 December 2011.

van Ittersum MK, Cassman KG, Grassini P, Wolf J, Tittonell P, Hochman Z, 2013. Yield gap analysis with local to global relevance A review. Field Crops Res. 143:4-17.

van Oort PAJ, Saito K, Dieng I, Grassini P, Cassman KG, van Ittersum MK, 2017. Can yield gap analysis be used to inform $\mathrm{R}$ \& D prioritization? Glob. Food Sec. 12:109-18.

van Wart J, Kersebaum KC, Peng S, Milner M, Cassman KG, 2013. Estimating crop yield potential at regional to national scales. Field Crops Res. 143:34-43. 